\title{
Seedling Emergence of Common Bean Accessions under Suboptimal Temperature
}

\author{
Parthiba M. Balasubramanian'1, Albert Vandenberg'2, and Pierre J. Hucl² \\ Crop Development Centre, University of Saskatchewan, 51 Campus Drive, Saskatoon, SK, S7N 5A8, \\ Canada
}

AdDitional INDEX WORDs. Phaseolus vulgaris, abiotic stress, low temperature, maturity

\begin{abstract}
Aвstract. Suboptimal seedbed temperatures in early spring limit common bean (Phaseolus vulgaris L.) seedling emergence. This field study evaluated emergence of cultivated and wild common bean when subjected to suboptimal seedbed temperature. One hundred and eighty common bean accessions and three control cultivars were planted on 3 May at Saskatoon, Sask., in 2000 and 2001. Percent emergence, cumulative thermal units to $50 \%$ anthesis and to $50 \%$ maturity, and seed yield were determined. The seedbed temperature during the 2 weeks after planting ranged between 1 and 18 ${ }^{\circ} \mathrm{C}$ in 2000 , and 5 and $17^{\circ} \mathrm{C}$ in 2001. At 20 days after planting, emergence in accession G8823 was significantly greater than the control cultivars in 2000. 'CDC Nighthawk', a black bean control cultivar was comparable in emergence to G8823 at 30 days after planting. A similar trend was observed in 2001 with the exception that emergence was greater at 30, 40, and 50 days after planting due to a warmer seedbed. 'CDC Nighthawk' was among the earliest to mature, although it required a significantly higher cumulative thermal unit to anthesis compared to most other accessions. G8823 could serve as a parent to develop elite bean cultivars with emergence at suboptimal seedbed temperatures.
\end{abstract}

Seedbed temperatures below $15^{\circ} \mathrm{C}$ are suboptimal for seed germination and emergence of common bean seedlings (Scully and Waines, 1988). Many common bean production regions of Canada, United States, and Europe experience suboptimal seedbed temperatures during planting in early spring (Balasubramanian, 2002; Dickson and Boettger, 1984; Kooistra, 1971). In the Dark Brown (Chernozem) and Black (Chernozem) soil zones of the Saskatchewan province, abiotic constraints to dry bean production include poor emergence due to cool wet soils of early spring, and the risk of late spring and early fall frosts. The mean daily soil temperature at a planting depth of $5 \mathrm{~cm}$ for Saskatoon (Dark Brown soil zone) indicates optimum seedbed temperature (20 to $30{ }^{\circ} \mathrm{C}$ ) is usually achieved after 21 May, thus delaying dry bean planting to late May. Late May planting ensures uniform seedling establishment, but the bean crop is vulnerable to early fall frost. The short growing season (105 to 110 frost-free days) on the prairies requires a dry bean breeding strategy involving development of cultivars either with early maturity to enable late May planting or with the ability to emerge under suboptimal seedbed temperatures to enable early May planting. Currently, most bean breeding programs are actively breeding for earlier maturity.

Common bean cultivars with improved emergence at suboptimal seedbed temperatures may enable early spring planting and therefore, extend the growing season. Selection for emergence at suboptimal temperatures has been widely reported in com-

Received for publication 20 Oct. 2003. Accepted for publication 1 Mar. 2004. This paper is part of a thesis submitted by Parthiba M. Balasubramanian in partial fulfillment of the requirements for a PhD degree at the Univ. of Saskatchewan. Financial support of scholarships from the College of Agriculture, Univ. of Saskatchewan, and Don Jaques Memorial Scholarship from the Saskatchewan Pulse Growers to the first author, and the technical assistance of the Pulse Crew, Crop Development Centre are gratefully acknowledged. The authors would also like to acknowledge the Genetic Resources Unit of the International Center for Tropical Agriculture, Cali, Colombia for the seeds. We thank Kirstin Bett and Thandiwe Nleya for reviewing the manuscript prior to submission, and the two anonymous reviewers and the associate editor for their comments.

${ }^{1}$ Current address: Agriculture and Agri-Food Canada-Morden Research Station, 100 - 101 Route 100, Morden, Manitoba, R6M 1 Y5.

Corresponding author: e-mail: parthibab@agr.gc.ca

${ }^{2}$ Professor. mon bean. Kooistra (1971) identified a navy bean genotype with $100 \%$ germination at a suboptimal temperature of $9^{\circ} \mathrm{C}$. Dickson (1971) selected several common bean lines from a population segregating for emergence at temperatures below $10^{\circ} \mathrm{C}$ in both controlled environment and the field. In the above study, nonwhite seedcoat color and resistance to seed decay by soil pathogens were strongly associated with superior germination at suboptimal temperatures. Differences among common bean genotypes for percent germination were highest at the lowest temperature (8 ${ }^{\circ} \mathrm{C}$ ) compared to 10,12 , or $18{ }^{\circ} \mathrm{C}$ (Zaiter et al., 1994). Furthermore, alternating temperature regimes of $10 / 8,12 / 8$, or $18 / 8{ }^{\circ} \mathrm{C}$ (12 $\mathrm{h}$ at each temperature) identified two additional genotypes with superior emergence compared to a constant temperature of $8{ }^{\circ} \mathrm{C}$, indicating a differential response of genotypes to the temperature treatment.

The mean growing temperature in the highlands of Central America is $18{ }^{\circ} \mathrm{C}$ and that in South America is $16^{\circ} \mathrm{C}$ (Singh, 1989). Germination and emergence response of wild common bean accessions from the high altitudes of the Sierra Madre and the Andes at suboptimal seedbed temperature is not known. Further, previous studies with common bean were conducted primarily in controlled environments with constant suboptimal temperatures. The objective of this study was to evaluate cultivated and wild common bean accessions for emergence under suboptimal temperatures in the field for use as parents in a bean breeding program.

\section{Materials and Methods}

Preliminary StUdiEs. Wild and cultivated common bean accessions, primarily from northern Europe, Japan, and the high altitudes $(>2000 \mathrm{~m}$ ) of the Sierra Madre and the Andes were obtained from the International Center for Tropical Agriculture, Cali, Colombia, in 1998. Seeds of $\approx 400$ accessions were increased in the phytotron facility of the College of Agriculture, Univ. of Saskatchewan. Plants were grown at $26 / 18^{\circ} \mathrm{C}$ with a 12 -h photoperiod. Seed from this increase was used in field studies. About 300 accessions were planted on 3 June 1999 at Saskatoon $\left(52^{\circ} 07^{\top} \mathrm{N}, 106^{\circ} 38^{\top} \mathrm{W}\right.$, elevation $\left.501 \mathrm{~m}\right)$, Sask., along with 17 
agronomically characterized bean cultivars and breeding lines (tester set) from several dry bean breeding programs in Europe, and North and South America. Thirty-six seeds per accession were planted $5 \mathrm{~cm}$ deep with a small plot hoe drill in a 1.8-m row. Seeds of wild bean accessions were scarified by nicking the seedcoat with a scalpel to overcome seedcoat-imposed dormancy. Growth habit and time to first anthesis and to $50 \%$ maturity were determined. Time to first anthesis was calculated as the number of days from planting to opening of the first flower bud. Time to physiological maturity was calculated as the number of days from planting to when $50 \%$ of the plants had pale yellow pods (buckskin stage).

Field EVALUATIONS DURING THE 2000 GROWING SEASON. Accessions that flowered earlier than the earliest genotype in the tester set in 1999 were included in this study. Wild bean accessions from altitudes of $2000 \mathrm{~m}$ and higher from the Sierra Madre and the Andes were also included. In total, seeds of 180 accessions and three control cultivars, CDC Whistler, CDC Nighthawk, and UI 906, were included. Origin, market class, growth habit, and 100-seed weight of control cultivars and selected accessions are presented in Table 1. Seeds of wild bean accessions were scarified as noted above. Seeds were treated with the fungicide Apron FL ( $0.146 \mathrm{~g} \cdot \mathrm{kg}^{-1}$ a.i. of seed $) 2 \mathrm{~d}$ prior to planting. Moisture content of the seed was between $10 \%$ and $12 \%$ (dry weight basis). Soil type at the trial site was a Dark Brown Chernozem clay loam. Mean annual precipitation at Saskatoon is $\approx 347 \mathrm{~mm}$, with an average of 110 frost-free days.

The experiment used an augmented design (Petersen, 1994) with six blocks. Each block consisted of 30 accessions and the three control cultivars. Due to limited seed availability, 50 or 100 seeds per accession were planted on 3 May at a depth of $5 \mathrm{~cm}$ with a small plot hoe drill. Plots were $1.2 \mathrm{~m}$ long and consisted of four rows spaced $30 \mathrm{~cm}$ apart. Percent emergence at 20,30, 40 , and $50 \mathrm{~d}$ after planting was determined in the entire plot. A 1-m section of the two center rows was used to measure anthesis, maturity, and yield for those accessions that were initially planted using 100 seeds. Time to anthesis was calculated as the number of days from planting to when $50 \%$ of the plants had at least one open flower. Time to physiological maturity was calculated as described above. Cumulative thermal units (CTUs) in degree Celsius days from planting to $50 \%$ anthesis or physiological maturity of $50 \%$ of plants was calculated using the formula CTU = $\Sigma\left[\left(\mathrm{T}_{\max }+\mathrm{T}_{\min } / 2\right)-\mathrm{T}_{\text {base }}\right]$ (Boote and Gardner, 1998). The $\mathrm{T}_{\max }$ and $\mathrm{T}_{\text {min }}$ were maximum and minimum air temperatures, respectively, at $1 \mathrm{~m}$ height in the field. The base temperature $\left(\mathrm{T}_{\text {base }}\right)$ was $8{ }^{\circ} \mathrm{C}$ (Hall, 2001). Plants were harvested by hand and seed yield was determined on a dry weight basis. A random sample of 100 seeds was taken from the bulk yield to determine 100-seed weight (dry weight basis) and percent frost damaged seed.

Soil temperature at the planting depth $(5 \mathrm{~cm})$ was monitored by thermocouples connected to a datalogger (Campbell Scientific Canada Corp., Edmonton, Albr.) for up to $50 \mathrm{~d}$ from planting. Air temperature at $1 \mathrm{~m}$ height from the soil surface was monitored throughout the growing season. Trait means for control cultivars were subjected to analysis of variance (ANOVA) appropriate for a randomized complete-block design (RCBD) to estimate the experimental error, which was then used to construct standard error of differences for the various comparisons. Adjustments of entry means for block differences were based on the difference between the mean of the control cultivars in a given block and the mean of the control cultivars over the entire trial (Petersen, 1994). Mean separation was done using the LSD. Block and cultivar in the ANOVA were considered as random and fixed effects, respectively.

FiELD EVALUATIONS DURING THE 2001 GROWING SEASON.Based on emergence at $20 \mathrm{~d}$ after planting in the 2000 growing season, five accessions with the highest emergence (G7551, G8090, G8823, G9345, G9430), and five accessions with no emergence (G746, G991, G5024, G19504, G19899) along with the three control cultivars were planted on 3 May 2001 to confirm the emergence results observed in the previous growing season. The experimental design was a RCBD with two replicates. Fifty Apron-treated seeds per accession per replicate were planted. Three-row instead of four-row plots were used in 2001. Percent emergence was determined as described above. A 1-m section of the center row was used to determine all other traits. Soil and air temperatures were monitored as described above.

\section{Results}

The 2001 growing season was relatively warmer and received less precipitation compared to the 2000 growing season and the long-term average (Table 2). The maximum air temperature during the 2001 growing season was 1 to $4^{\circ} \mathrm{C}$ warmer than the long-term average (Table 2). Precipitation was lower than the long-term aver- 
age during May and June of both 2000 and 2001, and much lower than the average during Aug. and Sept. 2001 (Table 2). Seedbed temperature during the first 2 weeks after planting ranged between 1 and $18^{\circ} \mathrm{C}$ during the 2000 growing season, and between 5 and $17^{\circ} \mathrm{C}$ during the 2001 growing season (Fig. 1).

STAND ESTABLISHMENT IN 2000. The differences in percent emergence among the control cultivars, CDC Whistler, CDC Nighthawk, and UI 906, were significant at all sampling times except at $20 \mathrm{~d}$ after planting (Table 3). At $20 \mathrm{~d}$ after planting (23 May, the conventional planting date for dry bean cultivars), two navy bean accessions, G8823 and G9345 (cv. Sanilac), had a significantly greater emergence compared to the control cultivars (Table 3). 'CDC Nighthawk' was equivalent in emergence to G8823 at 30 $\mathrm{d}$ after planting. At $50 \mathrm{~d}$ after planting, emergence for several accessions was below $50 \%$ including the control cultivar, CDC Whistler (Table 3). Wild bean accessions had little or no emergence for up to $30 \mathrm{~d}$ after planting with the exception of G23450 and G23554A, both of which had a emergence of $16 \%$.

StAnd ESTABLishment in 2001. Significant differences among common bean accessions and control cultivars were observed for emergence at all sampling times (Table 3). Emergence trend was similar to that observed in 2000, except that the warmer seedbed in late May and early June enhanced emergence at 30, 40, and $50 \mathrm{~d}$ after planting (Fig. 1, Table 3). At $20 \mathrm{~d}$ after planting, the two navy bean accessions, G8823 and G9345, had the highest percent emergence, although they were not significantly different from the control cultivar, CDC Nighthawk (Table 3). At $30 \mathrm{~d}$ after planting, all genotypes had $>60 \%$ emergence with the exception of 'UI 906', G746, G991, and G19899.

ANTHESIS, MATURITY, AND SEED YIELD. In 2000, the differences among control cultivars were significant for CTUs to $50 \%$ maturity, seed yield, 100-seed weight, and percent frost-damaged

Table 2. Mean monthly maximum and minimum air temperature and precipitation during the 2000 and 2001 growing seasons and long-term average at Saskatoon, Sask. ${ }^{\mathrm{z}}$

\begin{tabular}{|c|c|c|c|c|}
\hline Month & Temp/precipitation & 2000 & 2001 & 30-year avg \\
\hline \multirow[t]{3}{*}{ May } & $\mathrm{T}_{\max }\left({ }^{\circ} \mathrm{C}\right)$ & 18.2 & 20.9 & 18.4 \\
\hline & $\mathrm{T}_{\min }\left({ }^{\circ} \mathrm{C}\right)$ & 2.7 & 3.9 & 4.5 \\
\hline & Precipitation (mm) & 16.4 & 21.6 & 44.2 \\
\hline \multirow[t]{3}{*}{ June } & $\mathrm{T}_{\max }\left({ }^{\circ} \mathrm{C}\right)$ & 21.3 & 22.8 & 23.0 \\
\hline & $\mathrm{T}_{\min }\left({ }^{\circ} \mathrm{C}\right)$ & 7.2 & 8.0 & 9.4 \\
\hline & Precipitation (mm) & 49.8 & 38.3 & 63.4 \\
\hline \multirow[t]{3}{*}{ July } & $\mathrm{T}_{\max }\left({ }^{\circ} \mathrm{C}\right)$ & 25.3 & 27.4 & 25.4 \\
\hline & $\mathrm{T}_{\min }\left({ }^{\circ} \mathrm{C}\right)$ & 12.0 & 11.9 & 11.7 \\
\hline & Precipitation (mm) & 82.8 & 52.2 & 58.0 \\
\hline \multirow[t]{3}{*}{ August } & $\mathrm{T}_{\max }\left({ }^{\circ} \mathrm{C}\right)$ & 24.2 & 28.8 & 24.5 \\
\hline & $\mathrm{T}_{\min }\left({ }^{\circ} \mathrm{C}\right)$ & 9.4 & 10.7 & 10.3 \\
\hline & Precipitation (mm) & 42.0 & 6.0 & 36.8 \\
\hline \multirow[t]{3}{*}{ September } & $\mathrm{T}_{\max }\left({ }^{\circ} \mathrm{C}\right)$ & 19.3 & 22.3 & 17.7 \\
\hline & $\mathrm{T}_{\min }\left({ }^{\circ} \mathrm{C}\right)$ & 4.0 & 5.4 & 4.6 \\
\hline & Precipitation (mm) & 27.0 & 7.6 & 32.1 \\
\hline
\end{tabular}

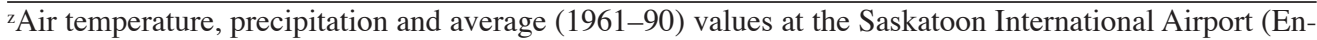
vironment Canada, 2000, 2001).

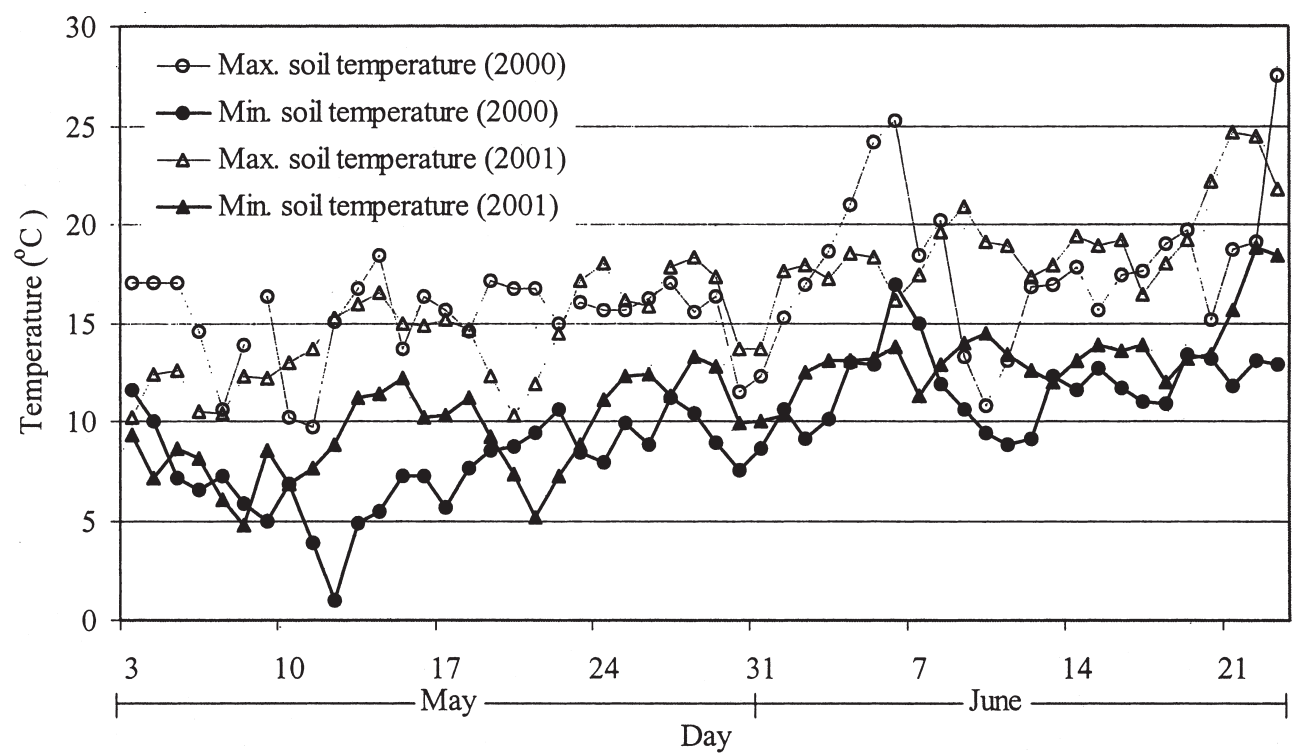

Fig. 1. Maximum and minimum daily soil temperatures at 5-cm depth during Spring 2000 and 2001 at the Preston field plot, Saskatoon, Sask. 
Table 3. Means for percent emergence at 20, 30, 40, and $50 \mathrm{~d}$ after planting of common bean cultivars and accessions grown at Saskatoon, Sask., during 2000 and 2001.

\begin{tabular}{|c|c|c|c|c|c|c|c|c|}
\hline \multirow[b]{3}{*}{ Cultivar/accession } & \multicolumn{8}{|c|}{ Emergence after planting } \\
\hline & \multicolumn{4}{|c|}{2000} & \multicolumn{4}{|c|}{2001} \\
\hline & $20 \mathrm{~d}$ & $30 \mathrm{~d}$ & $40 \mathrm{~d}$ & $\overline{50 \mathrm{~d}}$ & $20 \mathrm{~d}$ & $30 \mathrm{~d}$ & $40 \mathrm{~d}$ & $50 \mathrm{~d}$ \\
\hline & & & & & & & & \\
\hline CDC Whistler & 1.3 & 24.2 & 47.7 & 49.7 & 11.0 & 84.0 & 90.0 & 90.0 \\
\hline CDC Nighthawk & 1.7 & 70.7 & 89.3 & 91.0 & 17.0 & 95.0 & 98.0 & 98.0 \\
\hline UI 906 & 7.5 & 16.7 & 87.3 & 93.7 & 0 & 32.0 & 97.0 & 97.0 \\
\hline G7551 & 7.8 & 49.5 & 67.5 & 75.1 & 0 & 83.0 & 94.0 & 94.0 \\
\hline G8090 & 5.2 & 32.5 & 62.8 & 64.4 & 1.0 & 63.0 & 78.0 & 78.0 \\
\hline G8823 & 30.2 & 75.5 & 83.8 & 89.4 & 25.0 & 85.0 & 94.0 & 94.0 \\
\hline G9345 & 49.8 & 84.5 & 91.5 & 93.1 & 25.0 & 81.0 & 92.0 & 92.0 \\
\hline G9430 & 8.8 & 50.5 & 74.8 & 77.1 & 0 & 71.0 & 94.0 & 96.0 \\
\hline G746 & 0 & 3.9 & 69.1 & 80.8 & 0 & 36.0 & 97.0 & 99.0 \\
\hline G991 & 0 & 0 & 61.1 & 88.8 & 0 & 47.0 & 96.0 & 97.0 \\
\hline G5024 & 0 & 38.5 & 89.8 & 89.8 & 0 & 70.0 & 98.0 & 99.0 \\
\hline G19504 & 0 & 0 & 80.8 & 87.4 & 0 & 64.0 & 97.0 & 97.0 \\
\hline G19899 & 0 & 0 & 69.8 & 81.4 & 0 & 9.0 & 92.0 & 94.0 \\
\hline $\mathrm{LSD}_{0.05}{ }^{\mathrm{z}}$ & 17.8 & 32.6 & 18.0 & 19.4 & 13.4 & 27.9 & 7.8 & 6.6 \\
\hline
\end{tabular}

zDue to the augmented experimental design, the LSD in the year 2000 is to compare an accession with a control cultivar.

seed (Tables 4 and 5). The CTUs to 50\% anthesis for the control cultivars ranged from $527{ }^{\circ} \mathrm{C}$ days for 'CDC Nighthawk' to $549^{\circ} \mathrm{C}$ days for 'CDC Whistler' (Table 4). The CTUs to $50 \%$ anthesis of common bean accessions ranged from $374{ }^{\circ} \mathrm{C}$ days for $\mathrm{G} 9509$ to $797^{\circ} \mathrm{C}$ days for G5478 (cv. Tara). Among the two accessions with high emergence at $20 \mathrm{~d}$ after planting, G8823 required significantly less CTUs to $50 \%$ anthesis compared to control cultivars (Table 4). Due to photoperiod sensitivity, only 112 of the 180 accessions flowered prior to 10 Aug. Further, of the 112 accessions, only 57 matured prior to the first fall frost on 23 Sept. The CTUs to $50 \%$ maturity for the accessions ranged from $950{ }^{\circ} \mathrm{C}$ days for $\mathrm{G} 7524$ to $1141^{\circ} \mathrm{C}$ days for G8807. The CTUs to $50 \%$ maturity, seed yield, 100 -seed weight, and percent frostdamaged seed of accessions G8823 and G9345 were equivalent to 'CDC Nighthawk' (Tables 4 and 5).

In 2001, differences among accessions and control cultivars were significant for CTUs to $50 \%$ anthesis and $50 \%$ maturity (Table 4). Of the three control cultivars and 10 accessions evaluated, G746 and G19899 failed to flower and therefore did not mature in both 2000 and 2001. In contrast, accessions G991 and G19504 flowered but failed to mature prior to the first killing frost in both years. The above four accessions also failed to emerge by $20 \mathrm{~d}$ after planting in both 2000 and 2001 (Table 3). Accession G7551 required the least CTUs to 50\% anthesis in both years (Table 4). With the exception of accessions G9345 in 2001 and G9430 and G5024 in both 2000 and 2001, other accessions were comparable to 'CDC Nighthawk' for maturity.

\section{Discussion}

Planting in early May ensured that common bean seeds were subjected to suboptimal temperatures during germination and emergence (Fig. 1). Appearance of hypocotyl hook at the soil surface was first observed at $15 \mathrm{~d}$ from planting. A large variation in emergence was observed among common bean accessions, particularly at 20 and $30 \mathrm{~d}$ after planting (Table 3). Emergence for most accessions was poor at $20 \mathrm{~d}$ after planting, but increased over time with warming of the seedbed in mid-June, indicating good seed quality and viability under suboptimal seedbed tem- peratures. At temperatures below $10^{\circ} \mathrm{C}$, Kooistra (1971) observed little or no response in common bean germination for $\approx 14 \mathrm{~d}$. Poor emergence in a few accessions even after $50 \mathrm{~d}$ from planting is likely due to the relatively colder seedbed in 2000 compared to 2001 (Table 3, Fig. 1). Emergence in these accessions may have continued after the last emergence count. Further, below average precipitation during May and June in both years may have also reduced percent emergence of bean accessions. The interaction of suboptimal seedbed temperature and low water potential on germination and emergence of common bean is not known.

Two navy bean accessions, G8823 and G9345, had superior emergence when planted under suboptimal seedbed temperatures in both years (Tables 2 and 3). The accession G8823 was consistent in its emergence ( $30 \%$ in 2000 vs. $25 \%$ in 2001) compared to G9345 (50\% in 2000 vs. $25 \%$ in 2001) at $20 \mathrm{~d}$ after planting. Dickson (1971) in common bean, and Legesse and Powell (1992) in cowpea (Vigna unguiculata L.), observed poor germination of white/light-colored seeds under suboptimal temperatures compared to genotypes with dark seedcoat, primarily due to the susceptibility of the light-colored seeds to soil-borne fungal pathogens. Fungicidal seed treatment in our study may have reduced the confounding effect of some of the soil pathogens on poor emergence of accessions with light-colored seedcoat.

Common bean radicles that emerged at $8{ }^{\circ} \mathrm{C}$ were either weak or rotted and died compared to those radicles that emerged at 10 or $12{ }^{\circ} \mathrm{C}$ (Dickson and Boettger, 1984). Therefore, Dickson and Boettger (1984) argued that cold-tolerant lines would remain dormant until the germination medium is at least 10 to $12^{\circ} \mathrm{C}$. In this study, although common bean seeds were subjected to seedbed temperatures of below $10^{\circ} \mathrm{C}$ in the field (Fig. 1), the accessions G8823 and G9345 and the control cultivar, CDC Nighthawk, had between $89 \%$ and $98 \%$ emergence at $50 \mathrm{~d}$ after planting in both years, indicating little or no effect of suboptimal temperatures on final plant stand establishment (Table 3). Up to $30 \mathrm{~d}$ after planting, when the soil temperatures were generally below $15^{\circ} \mathrm{C}$ (Fig. 1), 'UI 906' had an emergence of $17 \%$ in 2000 and $32 \%$ in 2001 (Table 3). With an increase in soil temperature in mid-June, emergence in 'UI 906' increased to between $87 \%$ and $97 \%$. The temporal delay in emergence in 'UI 906' and in accessions with 
Table 4. Means for cumulative thermal units to $50 \%$ anthesis and to $50 \%$ maturity of common bean cultivars and accessions grown at Saskatoon, Sask., during 2000 and 2001.

\begin{tabular}{|c|c|c|c|c|}
\hline \multirow[b]{2}{*}{ Cultivar/accession } & \multicolumn{2}{|c|}{$\begin{array}{l}\text { Cumulative thermal units to } \\
50 \% \text { anthesis }\end{array}$} & \multicolumn{2}{|c|}{$\begin{array}{c}\text { Cumulative thermal units to } \\
50 \% \text { maturity }\end{array}$} \\
\hline & 2000 & 2001 & 2000 & 2001 \\
\hline & $\begin{array}{ll}---- \\
-\cdots\end{array}$ & $--^{\circ}$ & - n & ------ \\
\hline CDC Whistler & 549 & 530 & 1070 & 1032 \\
\hline CDC Nighthawk & 527 & 530 & 959 & 1008 \\
\hline UI 906 & 545 & 623 & 1004 & 1060 \\
\hline G7551 & 381 & 426 & 1011 & 945 \\
\hline G8090 & 492 & 516 & 1015 & 1027 \\
\hline G8823 & 435 & 503 & 978 & 1094 \\
\hline G9345 & 523 & 516 & 1012 & 1120 \\
\hline G9430 & 547 & 583 & 1046 & 1177 \\
\hline G5024 & 609 & 644 & 1078 & 1125 \\
\hline $\operatorname{LSD}_{0.05}{ }^{\mathrm{z}}$ & 51 & 61 & 61 & 96 \\
\hline
\end{tabular}

${ }^{2}$ Due to the augmented experimental design, the LSD in the year 2000 is to compare an accession with a control cultivar.

Table 5. Means for seed yield, 100-seed weight, and percent frost damaged seed of common bean cultivars and accessions grown at Saskatoon, Sask., during 2000 and 2001.

\begin{tabular}{|c|c|c|c|c|c|c|}
\hline \multirow[b]{2}{*}{ Cultivar/accession } & \multicolumn{2}{|c|}{ Yield $/ \mathrm{m}^{2}$} & \multicolumn{2}{|c|}{$100-$ seed wt } & \multicolumn{2}{|c|}{ Frost-damaged seed } \\
\hline & 2000 & 2001 & 2000 & 2001 & 2000 & 2001 \\
\hline & ------ & ------ & - & 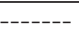 & --- & - \\
\hline CDC Whistler & 187 & 145 & 15 & 17 & 8 & 1 \\
\hline CDC Nighthawk & 450 & 120 & 17 & 18 & 0 & 0 \\
\hline UI 906 & 359 & 166 & 14 & 13 & 1 & 3 \\
\hline G7551 & 548 & 170 & 26 & 25 & 13 & 1 \\
\hline G8090 & 231 & 87 & 17 & 17 & 6 & 2 \\
\hline G8823 & 261 & 144 & 18 & 19 & 2 & 0 \\
\hline G9345 & 506 & 143 & 16 & 17 & 1 & 1 \\
\hline G9430 & 249 & 70 & 19 & 16 & 8 & 3 \\
\hline G5024 & $403^{z}$ & 144 & 24 & 24 & 0 & 0 \\
\hline $\operatorname{LSD}_{0.05}{ }^{\mathrm{z}}$ & 200 & NS & 2 & 3 & 6 & NS \\
\hline
\end{tabular}

${ }^{\mathrm{x}}$ Due to the augmented experimental design, the LSD in the year 2000 is to compare an accession with a control cultivar.

ss Nonsignificant.

a similar emergence pattern may be due to their requirement for high temperature maxima or an accumulation of certain degree days prior to start of germination and/or emergence. In canola (Brassica napus L.) cv. Westar, Nykiforuk and Johnson-Flanagan (1999) observed a temporal delay in germination at $10^{\circ} \mathrm{C}$ that did not affect the overall success of germination. The germination proceeded rapidly if the required equivalent of 16 to 24 degree days occurred before germination. However, at $6{ }^{\circ} \mathrm{C}$, delay and nonuniform germination due to both thermal and developmental effects was observed.

Common bean accessions could be broadly divided into three groups based on their emergence response at suboptimal seedbed temperatures. The first group consisted of accessions with emergence usually occurring between 20 and $30 \mathrm{~d}$ after planting (i.e., in late May, e.g., G8823, G9345, and 'CDC Nighthawk'). The second group consisted of accessions with a temporal delay in emergence due to suboptimal seedbed temperatures (e.g., G746 and 'UI 906'). A substantial increase in emergence was observed only after $30 \mathrm{~d}$ from planting (i.e., in mid-June) and the viability of seeds was not affected. The third group consisted of accessions with reduced emergence when planted at suboptimal seedbed temperatures (e.g., G8090). The extent of delay and nonuniformity of emergence due to suboptimal seedbed temperatures could not be established in this study because the accessions were not planted under optimal temperature regimes (i.e., in late May) in the field for comparison. The temporal delay and nonuniformity in germination in cold soils of early spring is an adaptive feature in common bean, which is sensitive to frost.

The environmental requirements for germination are correlated with the ecological conditions occurring in the habitat of the plant and the seed (Mayer and Poljakoff-Mayber, 1989). Near the Equator, night temperatures fall regularly below $10^{\circ} \mathrm{C}$ at altitudes of $2000 \mathrm{~m}$ and higher (Patterson et al., 1978). Plants that regularly experience temperatures below $10^{\circ} \mathrm{C}$ in their native habitat would be expected to be comparatively chilling resistant. For example, in Lycopersicon hirsutum, a wild relative of the cultivated tomato ( $L$. esculentum Mill.), genotypes collected at high altitudes of the Andes (2100 and $3100 \mathrm{~m}$ ) had higher germination at an alternating temperature regime of $15 / 5{ }^{\circ} \mathrm{C}(12$ $\mathrm{h}$ at each temperature) compared to those collected from lower altitudes (Patterson et al., 1978). The accession from $3100 \mathrm{~m}$ also exhibited the lowest temperature for greening of cotyledons. Unlike in the wild relative of tomato, the wild relatives of common bean, $P$. vulgaris var. mexicanus and $P$. vulgaris var. aborigineus from the high altitudes of the Sierra Madre and the Andes, respectively, showed poor or no emergence under suboptimal temperatures in the field (data not shown). Seedcoat integrity has been implicated in reducing imbibitional chilling injury in pea (Pisum sativum L.) seeds (Tully et al., 1981). Seeds of the wild relatives of common bean were scarified by nicking the seedcoat to overcome seedcoat-induced dormancy. Hence the poor emergence in these accessions may partly be attributed to the enhanced chilling injury due to loss of seedcoat integrity. The confounding effect of imbibitional chilling injury on early spring emergence needs to be overcome prior to utilizing wild relatives in the improvement of suboptimal temperature emergence in common bean. The imbibitional chilling injury could partly be overcome by slow imbibition of seeds (Chen et al., 1983). Loss of seedcoat integrity and therefore the imbibitional chilling injury in scarified seeds of wild bean may be overcome by coating seeds with a layer of polymer that is commonly used in fall-seeded crops to slow the imbibition process.

Large year-to-year variation was observed in this study for anthesis, maturity, and yield of bean accessions. Inference for anthesis, maturity, and yield traits is conservative due to the augmented experimental design used in 2000 and fewer accessions evaluated in 2001. In 2000, due to photoperiod sensitivity, only 112 of the 180 accessions flowered prior to 10 Aug. Further, G19504 was the only accession from high altitudes that flowered within the sampling period but failed to mature in both years. 
'CDC Nighthawk' was among the earliest to mature, although it required significantly higher CTUs to $50 \%$ anthesis compared to accessions from northern Europe (Table 4). Although, accession G8823 was early to emerge and to flower, its CTUs to $50 \%$ maturity and yield were similar to 'CDC Nighthawk' in both years (Tables 3, 4, and 5). If total vegetative growth determines crop yield, a genotype that flowered late but filled pods rapidly would be preferred for regions with a short growing season (White and Izquierdo, 1991). Correlation coefficient between CTUs to $50 \%$ anthesis and CTUs to $50 \%$ maturity, and growth habit (determinate and indeterminate) of cultivars was not significant (data not shown).

In conclusion, this study identified common bean accessions with diverse emergence and emergence patterns. Accessions G8823 and G9345 with a relatively high emergence in early spring are tolerant to suboptimal seedbed temperatures. Accession G8090 with poor emergence at all sampling times in both years is sensitive to suboptimal seedbed temperatures. Although 'UI 906' and G746 had poor emergence in early spring, a substantial increase in emergence was observed with a warmer seedbed. Emergence in these accessions is characterized by a temporal delay when planted under suboptimal seedbed temperature. The accession G8823 could serve as a parent to develop elite bean cultivars with emergence under suboptimal temperatures, particularly for regions with a low risk of frost at the seedling stage and in the high altitudes of the tropics. However, for northern prairies with a short growing season and a high risk of late spring frosts, breeding dry bean cultivars with an emergence similar to 'UI 906' or 'CDC Nighthawk' would enable mid-May or earlier plantings of dry bean. This strategy would considerably slow the emergence of seedlings until after the threat of late spring frosts has receded. However, the relationship between early stand establishment due to early spring planting and early maturity and seed yield needs to be investigated by planting dry bean cultivars at both suboptimal (early to mid-May) and optimal (late May) seedbed temperatures across the target environment.

\section{Literature Cited}

Balasubramanian, P. 2002. Selection for chilling and freezing resistance in common bean. PhD Thesis. Univ. of Sask., Saskatoon, Canada. Boote, K.J. and F.P. Gardner. 1998. Temperature, p. 135-153. In: T.R.
Sinclair and F.P. Gardner (eds.). Principles of ecology in plant production, CAB Intl., Wallingford, Oxon, U.K.

Chen, T.H.H., S.D.K. Yamamoto, L.V. Gusta, and A.E. Slinkard. 1983. Imbibitional chilling injury during chickpea germination. J. Amer. Soc. Hort. Sci. 108:944-948.

Dickson, M.H. 1971. Breeding beans, Phaseolus vulgaris L., for improved germination under unfavorable low temperature conditions. Crop Sci. 11:848-850.

Dickson, M.H. and M.A. Boettger. 1984. Emergence, growth, and blossoming of bean (Phaseolus vulgaris) at suboptimal temperatures. J. Amer. Soc. Hort. Sci. 109:257-260.

Environment Canada. 2000. Annual meteorological summary, Saskatoon, Sask.

Environment Canada. 2001. Annual meteorological summary, Saskatoon, Sask.

Hall, A.E. 2001. Crop responses to environment. CRC Press, Boca Raton, Fla.

Kooistra, E. 1971. Germinability of beans (Phaseolus vulgaris L.) at low temperatures. Euphytica 20:208-213.

Legesse, N. and A.A. Powell. 1992. Comparisons of water uptake and imbibition damage in eleven cowpea cultivars. Seed Sci. Technol. 20:173-180.

Mayer, A.M. and A. Poljakoff-Mayber. 1989. The germination of seeds. 4th ed. Pergamon Press, Oxford, U.K.

Nykiforuk, C.L. and A.M. Johnson-Flanagan. 1999. Storage reserve mobilization during low temperature germination and early seedling growth in Brassica napus. Plant Physiol. Biochem. 37:939-947.

Patterson, B.D., R. Paull, and R.M. Smillie. 1978. Chilling resistance in Lycopersicon hirsutum Humb. \& Bonpl., a wild tomato with a wide altitudinal distribution. Austral. J. Plant Physiol. 5:609-617.

Petersen, R.G. 1994. Agricultural field experiments: Design and analysis. Marcel Dekker, New York.

Scully, B. and J.G. Waines. 1988. Ontogeny and yield response of common and tepary beans to temperature. Agron. J. 80:921-925.

Singh, S.P. 1989. Patterns of variation in cultivated common bean (Phaseolus vulgaris, Fabaceae). Econ. Bot. 43:39-57.

Tully, R.E., M.E. Musgrave, and A.C. Leopold. 1981. The seed coat as a control of imbibitional chilling injury. Crop Sci. 21:312-317.

White, J.W. and J. Izquierdo. 1991. Physiology of yield potential and stress tolerance, p. 287-382. In: A. van Schoonhoven and O. Voysest (eds.). Common beans: Research for crop improvement. CAB Intl., Wallingford, U.K., and CIAT, Cali, Colombia.

Zaiter, H., E. Baydoum, and M. Sayyed-Hallak. 1994. Genotypic variation in the germination of common bean in response to cold temperature stress. Plant and Soil 163:95-101. 